\title{
The effect of puromycin on retention of a positively reinforced response in goldfish*
}

\author{
DONALD A. KRISTT and STEVEN J. FREIMARK† \\ Polytechnic Institute of Brooklyn, Brooklyn, N.Y. 11201 \\ and \\ KURT SALZINGER \\ Poly technic Institute of Brooklyn, Brooklyn, N.Y. 11201 and \\ Biometrics Research, New York State Department of Mental Hygiene \\ New York, N.Y. 10032
}

Two groups of goldfish were trained to strike a small target for food reintorcement. One group was injected with puromycin, the other with saline, immediately following training. On testing. 2 days later, puromycin fish performed as well as saline controls.

The hypothesis that "long-term" memory is associated with the synthesis of a special storage protein is an intriguing one. Several groups have approached this question by utilizing the antibiotic puromycin, a substance known to inhibit brain protein synthesis by more than $80 \%$ following intracranial injection (Brink et al, 1966; Flexner et al, 1962).

Agranoff et al (1966), working with shock avoidance conditioning in goldfish (Carassius auratus), have reported that puromycin, injected intracranially immediately after training, results in a "complete memory deficit" 3 days later. Agranoff believes that this memory deficit is causally related to the drug's inhibition of cerebral protein synthesis.

In an effort to clarify the behavioral effects of puromycin administration, Potts \& Bitterman (1967) performed two experiments which indicated that puromycin selectively blocked the consolidation of "conditioned fear," i.e., the learning of a response associated with an aversive situation.

The puromycin effect is also seemingly sensitive to the degree of learning. Both Agranoff \& Klinger (1964) and Potts \& Bitterman (1967) have found that overtraining Ss renders them refractory to puromycin.

These remarks raise the problem of how puromycin, which has nonspecific biochemical activity, can have a selective effect on behavior.

Since all these previous studies involve shocking the goldfish during training, the puromycin effect might be related to a particular state of the organism uniquely associated with the aversiveness of the training situation, e.g., arousal. To test this hypothesis, we undertook to train goldfish on a positively reinforced, nonaversive

*The authors thank Donald S. Phillips for his technical assistance.

$\div$ Part of this research was presented in partial fulfillment of the Master of Arts degree. Queens College of the City Lniversity of New York. task, which could nevertheless be learned in a relatively brief time period.

\section{METHOD}

The Ss were 32 goldfish /Carassius auratus) obtained from a local dealer. Fish varied in length from 8 to $12 \mathrm{~cm}$.

Fish were trained to strike a black circular target, $2.7 \mathrm{~cm}$ in diam. The target, mounted in a partition, was placed in the home tank during training and testing. After each response, a worm was automatically dropped in front of the target by a worm dispenser located overhead.

Fish were maintained in individual 21/2-gal tanks with the temperature kept at approximately $20^{\circ} \mathrm{C}$. For at least 3 weeks before the experiment, fish were fed 25 worms, one at a time, per day. The purpose of this was to train the fish to eat the worms rapidly. Two days before a fish was to be trained, it was adapted to the sound of the worm dispenser's solenoid, which appears to startle naive goldfish. Adaptation was accomplished by actuating the solenoid 30 times, at random intervals over $30 \mathrm{~min}$.

For the training session, a fish, in its home tank, was placed in a fluorescently lighted experimental chamber with the target in place. No shaping was used. The fish was allowed a maximum of $6 \mathrm{~h}$ in which to begin responding. If a fish did not begin within this period it was discarded from the sample. A fish was not considered to have begun responding until two responses were made within a 5 -min period. This criterion was adopted to avoid counting inadvertent responses. After responding began, the fish was allowed either $15 \mathrm{~min}$ or 20 responses, whichever occurred first. Timing and counting began with the first response. One worm was delivered for each response. After completion of training, the fish was immediately removed from the experimental chamber and injected with either 10 microliters of saline or
10 microliters of puromycin dihydrochloride.

Injections were made with either a 50or 100-microliter syringe through a 30 ga needle. A plastic stop was placed on the needle to allow penetration of the cranium to a depth of $2 \mathrm{~mm}$ below the surface of the skull over the optic tectum. The injection was made with the needle held at a 45-deg angle to the snout, bevel down, and inserted at the medial suture in line with the posterior margin of the orbits.

The puromycin was prepared in distilled water and neutralized to $\mathrm{pH} 7$. The concentration was 170 micrograms per 10 microliters. The saline injections were $.15 \mathrm{~N} \mathrm{NaCl}$.

Two days after the injection, each fish was again put in the experimental chamber and tested for retention. All the fish were tested for a period of $15 \mathrm{~min}$ from the first response.

\section{RESULTS}

Out of the 32 goldfish used, 6 did not begin responding within the $6 \cdot \mathrm{h}$ period and were discarded. Of the remaining 26 fish, 13 were randomly assigned to the puromycin group and the other 13 to the saline group.

Table 1 presents the rates of responding for training and testing sessions in both the saline and puromycin groups. The rates of responding for training were calculated by using the time required to make 20 responses or the number of responses made in $15 \mathrm{~min}$. Ten fish met the criterion of 20 responses, 16 were trained for $15 \mathrm{~min}$; half of each group were given puromycin, half saline injections. The response rates for the testing session were calculated by using the number of responses made in the same interval of time as was required to make 20 responses in the training session or (where this criterion was not met in training) the number of responses made in the $15-\mathrm{min}$ interval was used. ${ }^{1}$ Twelve fish made 90 responses (the maximum number of worms held by the worm dispenser) in a period that was shorter than that allotted by the above criterion. In these cases, the time required to make the 90 responses was used to calculate the rate.

The mean rates of responding for the puromycin group and the saline group before injection are fairly close, as are the rates for the two groups after injection. Application of a $t$ test for the difference between the puromycin and saline groups in the rate of responding on training showed that there is no significant difference in learning before injection $(\mathrm{t}=0.64, \mathrm{df}=24, \mathrm{p}>.05)$. The injection of puromycin or saline had no differential effect on retention since no significant difference was found in the rates of responding during testing between the two 
Table 1

Mean Rates of Responding (Responses/Minute) in the Puromycin and Saline Groups for the Training and Testing Sessions

\begin{tabular}{|c|c|c|c|c|c|}
\hline \multicolumn{3}{|c|}{ Puromycin } & \multicolumn{3}{|c|}{ Saline } \\
\hline $\begin{array}{l}\text { Fish } \\
\text { Number } \\
\end{array}$ & Training & Testing & $\begin{array}{c}\text { Fish } \\
\text { Number }\end{array}$ & Training & Testing \\
\hline 10 & $0.53 *$ & 1.60 & 14 & 2.41 & 3.85 \\
\hline 16 & 6.24 & 13.73 & 9 & $0.67 *$ & 0.13 \\
\hline 23 & $0.33^{*}$ & 1.20 & 22 & 2.33 & 10.48 \\
\hline 27 & $0.27 *$ & 0.20 & 25 & 1.75 & 0.98 \\
\hline 17 & $0.27 *$ & 0.47 & 29 & 4.26 & 8.95 \\
\hline 19 & 2.60 & 10.41 & 33 & $0.27^{*}$ & 6.00 \\
\hline 31 & 1.86 & 8.92 & 37 & $0.47^{*}$ & 1.47 \\
\hline 34 & 5.51 & 6.34 & 38 & 1.59 & 8.95 \\
\hline 40 & 1.95 & 5.67 & 39 & $0.53 *$ & 4.33 \\
\hline 43 & 3.12 & 7.50 & 41 & 2.23 & 5.02 \\
\hline 44 & $1.20^{*}$ & 2.80 & 46 & $0.67^{*}$ & 1.27 \\
\hline 47 & 2.27 & 5.91 & 49 & 3.97 & 4.16 \\
\hline 48 & 2.18 & 7.06 & 50 & 1.87 & 7.77 \\
\hline$\overline{\mathrm{X}}$ & 2.18 & 5.47 & $\overline{\mathrm{X}}$ & 1.77 & 4.85 \\
\hline
\end{tabular}

* $15 \mathrm{~min}$ of training

Table 2

Response Latencies (in Minutes) from Beginning of Session to First Response for Puromycin and Saline Groups on Training and Testing

\begin{tabular}{|c|c|c|c|c|c|}
\hline \multicolumn{3}{|c|}{ Puromycin } & \multicolumn{3}{|c|}{ Saline } \\
\hline $\begin{array}{c}\text { Fish } \\
\text { Number }\end{array}$ & Training & Testing & $\begin{array}{c}\text { Fish } \\
\text { Number }\end{array}$ & Training & Testing \\
\hline 10 & 291.63 & 5.45 & 14 & 315.66 & 3.00 \\
\hline 6 & 60.23 &. .75 & 9 & 71.97 & 9.65 \\
\hline 23 & 38.74 & 1.67 & 22 & 118.61 & 1.35 \\
\hline 27 & 211.00 & 0.16 & 25 & 20.72 & 2.27 \\
\hline 17 & 11.03 & 12.86 & 29 & 69.76 & 2.74 \\
\hline 19 & 196.09 & 0.92 & 33 & 71.14 & 1.16 \\
\hline 31 & 97.89 & 2.17 & 37 & 33.24 & 6.08 \\
\hline 34 & 11.45 & 0.04 & 38 & 116.46 & 0.99 \\
\hline 40 & 106.55 & 0.19 & 39 & 158.32 & 15.53 \\
\hline 43 & 173.27 & 1.27 & 41 & 26.65 & 4.33 \\
\hline 44 & 57.56 & 12.42 & 46 & 1.54 & 4.74 \\
\hline 47 & 5334 & 2.87 & 49 & 23.34 & 0.54 \\
\hline 48 & 42.48 & 0.98 & 50 & 62.96 & 1.47 \\
\hline$\overline{\mathrm{x}}$ & 104.64 & 3.29 & $\overline{\mathrm{X}}$ & 83.87 & 4.14 \\
\hline
\end{tabular}

groups $(\mathrm{t}=0.43, \mathrm{df}=24, \mathrm{p}>.05)$. In order to check that learning had occurred within each group, correlated t tests were applied to each group. Both groups showed a significant increase in response rate: for the puromycin group, $t=4.22(\mathrm{df}=12$, $\mathrm{p}<.005$, one-tailed); for the saline group, $\mathrm{t}=3.66(\mathrm{df}=12, \mathrm{p}<.005$, one-tailed $)$.

Table 2 presents the latencies from the beginning of the session to the first response for the puromycin and saline groups, both before and after training. The results are quite similar to those for the response rates. There is no significant difference between the two groups for the training session or for the testing session. For training, $t=0.63(d f=24, p>.05)$, for the testing session, $t=0.50(d f=24$, $\mathrm{p}>.05)$. Both groups show a significant improvement in the latency to the first response from training to testing and this again shows learning. For the puromycin group, the correlated $\mathrm{t}=4.14 \quad(\mathrm{df}=12$, $p<.005$, one-tailed): for the saline group, the correlated $\mathrm{t}=3.49(\mathrm{df}=12, \mathrm{p}<.005$, one-tailed).
The efficacy of our injection technique was tested in two ways. First, determination of the degree of inhibition of protein synthesis was carried out using $\mathrm{C}^{14}$. Leucine to label brain protein. Protein extraction was done according to the method of Siekevitz (1952). In the hour following puromycin injection, suppression of protein synthesis was almost complete (greater than $95 \%$ of nonpuromycin controls). Second, X-ray examination during injection of a radio-opaque solution demonstrated that the material was injected over the optic tectum.

\section{DISCUSSION}

Our results indicate, therefore, that the performance of goldfish injected with a large dose of puromycin was not different from that observed among saline controls when both were tested 2 days following training, i.e., puromycin did not induce a memory deficit. There are several possible explanations for this finding. One is that consolidation of the memory, i.e., the development of anergy to the drug, might have begun during the training session. If the duration of the session is too long or the response is repeated too frequently. consolidation might begin prior to the administration of puromycin. However, in the present experiment, one of the fish made the 20 responses within 3.12 min. another fish within $3.62 \mathrm{~min}$ : both fish received puromycin and both showed good retention. On this basis, it seems unlikely that the duration of the session could be too long. The other explanation, that the response was repeated too frequently, also seems unlikely, since a number of fish that made only four responses in the 15 -min training session showed good retention upon testing. The possibility still remains, though. that consolidation had taken place during the training session. Target pressing may be a fairly easy response for the goldfish to learn and may be readily consolidated. This would have to be tested in future experiments either by using a different task or by reducing the time and number of responses allowed with the present task.

Another alternative for explaining the results of the present experiment has already been mentioned; namely, the Potts \& Bitterman (1967) idea that puromycin selectively affects the consolidation of conditioned fear. Hence, goldfish trained in a positively reinforced, nonaversive situation would not be expected to show the effect. That puromycin has this specificity is difficult to reconcile with its rather uniform depression of protein synthesis. Another property of puromycin that could be considered in this context is its occult seizuregenic activity (Cohen et al. 1966). Cohen \& Barondes (1967) have suggested that in mice such occult seizures may be responsible for the amnestic effect of puromycin in much the same way that ECS produces a memory deficit (Davis et al, 1965). Moreover, puromycin can interact with other substances to modify its seizuregenic potential (Cohen \& Barondes, 1967). For instance, subconvulsive doses of the convulsant pentylenetetrazol potentiates the susceptibility to puromycin-induced seizures. On this basis, we suggest that the specificity of the puromycin effect may be explained by the production of some endogenous substance (e.g., epinephrine or cortisol), in response to an aversive training situation but not in a positively-reinforced one. The interaction of this humoral material with puromycin sufficiently potentiates puromycin's physiological effects so that the amnestic ones become manifest.

\section{REFERENCES}

$A C^{n} A$ NOFF, B. W. \& KLINGER. P. D. Puromycin effect on memory fixation in the goldfish. Science, 1964. 145, 952-953.

AGRANOFF, B. W. DAVIS, R. E.. \& BRINK, J. 
J. Chemical studies on memon fixition in goldfish. Brain Research. 1966. 1. 303-309.

BRINK. J. J., DAVIS, R. E., \& AGRA IOI I. B. W. Effects of purom ysin. acetoxycycloheximide and actinomycin $\mathrm{D}$ on protein synthesis in goldfish brain 5 . Journal of Neurochemistry, 1966, 13,889-896.

COHEN, H. D.. \& BARONDES, S. H. Puromycin effect on memory may be due to occult seizures. Science. 1967, 157, 333-334.

COHEX. H. D., ERVIN, F., \& BARONDFS. S. H. Puromycin and cycloheximide: Different effects on hippocampal electrical activity. Science. 1966, 154, 1557-1558.

DAVIS, R. E.. BRIGHT, P. J.. \& AGRANOFF, B. W. Fffect of ECS and puromycin on memory in fish. Journal of Comparative \& Physiological Pyychology, 1965, 60, 162-166.
ILIXNER, J, B.. FLEXIER, L, B, STELIAR, 1.. de la HABA, G.. \& ROBERTS, R. B. Inhibition of protein synthesis in brain and liaming and memory following puromycin. Journal of Veurachemistry, 1962, 9, 595-605. POTTS, 4., \& BITTERMAN, M. E. Puromycin and retention in goldfish. Science, 1967,158 , 1694-1696.

SIEKEVITZ. P. Lptake of radioactive alanine in vitro into the proteins of rat liver fractions. Joumal of Biological Chemistry, 1952, 195, 549-565.

\section{NOTE}

1. Fish No. 33 was reinforced only for the 30 responses completed in the first $5 \mathrm{~min}$. The rate was therefore taken to be 30 responses per $5 \mathrm{~min}$ or 6 responses per minute.

\title{
Self-punitive locomotor behavior in the Mongolian gerbil
}

\author{
R. CHRIS MARTIN \\ University of Missouri-Kansas City, Kansas City, Mo. 64110 \\ EVELYN RAGLAND \\ Hollins College, Hollins, Va. 24020 \\ and \\ KENNETH B. MELVIN \\ University of Alabama, University, Ala. 35486
}

This study was primarily a test of the generality of a behavioral phenomenon across species. Several investigations have shown that rats when punished for an aversively motivated response will maintain that response rather than abandon it. Similar treatments revealed that the Mongolian gerbil also showed such self-punitive behavior. Special characteristics of the gerbil were noted.

Punishment of an ongoing aversively motivated response may maintain, or even facilitate, performance (e.g., Brown,

\footnotetext{
* This research was supported in part by a gran to the first author from $\mathrm{Mr}$. F. Ot to Haas of the Haas Foundation, and in part by Grant 2189-2100 from LMKC to the first author.
}

Martin, \& Morrow, 1964; Melvin \& Martin, 1966). A number of investigators have studied this "vicious-circle" phenomenon through the analysis of locomotor behavior in the rat (see Brown, 1969). In fact, rats of various strains have been used in such studies. Recently, however, the generality of behavioral principles derived by use of laboratory rats has been severely questioned (Lockard, 1968). While one may not agree with many of Lockard's contentions, his article does emphasize the need for more studies that examine the generality of phenomena across species. In the present study treatment conditions of punishment-after-escape training were instituted during extinction of a runway response in an attempt to ascertain whether the gerbil species of the order Rodentia demonstrate "vicious-circle" behavior.

Gerbils differ from rats (especially laboratory rats) in many respects, e.g. their ecological niche, water intake, resistance to heat, type of habitat, and the discovery that a behavioral phenomenon found in rats is also shown by the gerbil would broaden the generality of that phenomenon significantly.

\section{SUBJECTS AND APPARATUS}

The Ss, 14 naive male gerbils (Meriones unguiculatus) of the Tumblebrook strain, were 13-14 weeks old, All Ss were deprived of food for $23 \mathrm{~h}$ before training.

The apparatus was a straight runway, 82 in. long and 12 in. high. A guillotine door, 12 in. from one end, divided the runway into a startbox and an alley 70 in. in length. At the other end of the runway, a second guillotine door separated the goalbox from the alley. The goalbox was $12 \times 18 \times 13.5$ in., painted black, and had a wooden floor and lid. In contrast, the startbox and alley were white, had floors consisting of $1 / 4$-in.-diam grid rods spaced $3 / 4$ in. apart, and had lids of Plexiglas.

Raising the doors turned on the shock and an electronic clock; this clock stopped and a second clock started when $S$ interrupted a photobeam 7 in. outside the startbox. The second clock stopped when $S$ broke a photobeam at the entrance of the goalbox, thus measuring alley time to the nearest $.01 \mathrm{sec}$.

\section{PROCEDURE}

Shock-escape training consisted of eight shaping trials followed by 35 acquisition trials. During shaping $S$ was placed onto the grid at successive distances of $1.5,3.0$, 4.5 , and $6 \mathrm{ft}$ from the goalbox. Each gerbil was given two trials for each distance. Between each trial $S$ remained in the goalbox for approximately $30 \mathrm{sec}$. The intensity of the scrambled shock was $1.0 \mathrm{~mA}$

During acquisition $S$ was placed in the startbox. The doors were then raised, turning on a $1.0-\mathrm{mA}$ shock. When $\mathrm{S}$ entered the goalbox, the doors were lowered to prevent retracing, and $S$ remained there for about $20 \mathrm{sec}$. The intertrial interval was approximately $30 \mathrm{sec}$. 